\title{
The Sevdalinka in Exile, Revisited: Young Bosnian Refugees' Music-Making in Ljubljana in the 1990s (A Note on Applied Ethnomusicology)
}

\author{
MIHA KOZOROG, ALENKA BARTULOVIĆ \\ Department of Ethnology and Cultural Anthropology, \\ Faculty of Arts, University of Ljubljana
}

\begin{abstract}
Scholars perceived the sevdalinka in exile as an evident expression of refugees' Bosnian identity. Although this aspect might be important, we think that the identity dimension of the sevdalinka was overemphasised. That is why we point to the appearance of the sevdalinka in Slovenia as a complex process of experiencing uncertainty and trauma of forced migration on the one hand, and youth creativity or a search for expressive freedom on the other. Hence, we aim to move the focus from the refugees' music life as collective experience to personal, highly individualised narratives. In addition, we argue that musical activities were organised in many aspects. An ethnomusicologist participated in these activities, therefore the work of applied ethnomusicology, together with its practice of strategic essentialisation of music, should be discussed as an integral part of the refugees' music-making process.
\end{abstract}

Key words: sevdalinka, war in Bosnia and Herzegovina, applied ethnomusicology, refugee music, young refugees

"In exile, I started to play the saz", writes the former refugee, Vesna Andree Zaimović, in the introduction to her Master's thesis on the musical expressions of war refugees from Bosnia and Herzegovina (BH) in European countries in the 1990 s. $^{1}$ She continues her story: as an ethnomusicology

\footnotetext{
${ }^{1}$ Although she focuses on refugees, her examination does not distinguish their cultural production in exile from the cultural production of the pre-war diaspora. In this article, however, refugee music-making is considered as a separate research issue. Refugees' lives in foreign environments are usually less routine than stably organised diasporic ways of living. The diaspora was not profoundly involved in refugees' cultural production, but such cases did exist - e.g. the Bosnian poet Josip Osti, who moved to Slovenia before the war and later ran a poetry workshop for young refugees as part of the Cultural Weekend for Children programme (discussed below).
} 
student, she was indeed aware of the saz and its place in Bosnian musical tradition, ${ }^{2}$ but "major political events had to happen for me to feel the need to start actively playing this instrument - and moreover, it was in Slovenia" (2003: 4). The war and exile made her yearn fervently for this instrument that was already marginal in the musical life of $\mathrm{BH}$ and superficially present in her life world. The same is true of the characteristic traditional song - the sevdalinka. Vesna and her compatriots in exile began desiring and resurrecting this musical-poetic form, which was largely disappearing in BH. After the war, playing the saz and performing sevdalinkas were thus proclaimed an expression of refugees' longing and belonging, an expression of identity. Andree Zaimović explicates this in the core argument of her research:

At a certain historic, social and political moment (the war in $\mathrm{BH}$ and the immediate post-war period) and among certain populations (physically displaced from indirect war danger, but still emotionally and intellectually connected with the motherland) the sevdalinka has proven to be an irreplaceable symbol of identity. (2001: 113; also 2003: 94)

The writings of Andree Zaimović remain a rare thoughtful analysis of the music-making of young Bosnian and Herzegovinian refugees in Ljubljana, the capital of Slovenia. Nevertheless, at a distance of more than a decade, they also invite us to critically engage with ethnomusicological interpretations of refugee music-making in exile. ${ }^{3}$ Writings on this topic give the impression that the musical expressions of refugees are unconditionally spontaneous, arising from an inner spirit shared by a refugee population. It appears as if music engagements are collective, something that "refugees" are simply prone to do, without distinguishing their various experiences, backgrounds and positioning in the new social contexts. In contrast, this article examines organisational and sociological aspects of refugee music-making in Ljubljana in the 1990s. The article is based on interviews with musicians and other participants, as well as on the authors' memories; Bartulović was a singer of

${ }^{2}$ The saz is a long-necked lute. The sevdalinka is often described as an intimate song, intended for performance in a small, secluded environment. As a song without extreme dynamics, it was traditionally performed by a single singer, without accompaniment or accompanied solely by the saz (or, more recently, the accordion) (Karača-Beljak and Talam 2009: 121). However, some Bosnian and Serbian Roma bands performed sevdalinkas in cafés and taverns already in the 19th century. Such bands made commercial recordings of sevdalinkas in Sarajevo as early as 1907 (Pennanen 2007).

${ }^{3}$ We doubt that the kind of critical engagement we aim to employ in this article was previously possible at all. During the war and exile, researchers had face-to-face contacts with refugees and were affected by their life stories and living conditions; hence, humanitarian considerations took precedence over scholarly questions. Consequently, a determined call for applied ethnomusicology to help refugees with specific knowledge of music emerged, improving the wellbeing of refugees and relations in new social contexts (Pettan 1995). 
the group Vali, and Kozorog has been impressed by the group Dertum for a long time.

We argue that specific relations and contexts in situ, as well as various larger and contingent ones, directed musicians towards the sevdalinka. Therefore, our aim is to shift the emphasis of the research on refugee musicmaking from the allegedly spontaneous, identity-driven and collective musical activity towards an approach that traces organised, multi-layered and highly individualised processes of musical coping with exile (see Diehl 2002). Furthermore, we will also reflect on how applied ethnomusicology working with refugees entails the danger of a strategic essentialisation of specific musical forms (see Hofman 2010).

\section{INTERPRETING REFUGEE MUSIC-MAKING IN EXILE}

During the war in BH between 1992 and 1995 and in the post-war period, music was an important part of refugees' experience of exile (Andree Zaimović 2001, 2003; Golemović 2002; Hemetek and Bajrektarević 2000; Pesek 1996; Pettan 1995, 1996, 2009; Terseglav 2001), and the sevdalinka was a coping mechanism for refugees' dealing with a foreign environment. Two music groups of young refugees were formed in Ljubljana, Vali and Dertum, both performing sevdalinkas (but never exclusively). Two other, less publicly exposed groups were also active, devoting their efforts to preserving the "heritage" of the sevdalinka: one formed in a refugee centre by the refugee musician, Amir Otanović (Terseglav 2001), ${ }^{4}$ the other was started as a "folk orchestra" for children by the refugee music pedagogue, Sabrija Džafić, at the Vodnik Manor House cultural centre. ${ }^{5}$

Between 1994 and 1998, Vesna Andree Zaimović was Vali's leader and music pedagogue. The group was, however, an outcome of endeavours by "cultural migrants", as she designates them, i.e. artists, pedagogues, journalists and other intellectuals. Her father, Vjekoslav Andree, a music pedagogue who emigrated from Sarajevo at the beginning of the war, was the leading figure among them. In January 1993, he initiated the refugees' programme Cultural Weekend for Children from Bosnia and Herzegovina at the Vodnik Manor House in Ljubljana (Andree Zaimović 2003: 71). Vali was just one among many projects in this humanitarian framework that aimed to

\footnotetext{
${ }^{4}$ This group's interpretations of sevdalinkas were recorded in 1994 by the folklorist Marko Terseglav at the Institute of Ethnomusicology of the Research Centre of the Slovenian Academy of Sciences and Arts.

${ }^{5}$ The latter two groups did not attract wider public attention in Slovenia, presumably because they strove to perform sevdalinkas in "folk pop" and "folklore" styles, which have not been embraced by the Slovenian audience.
} 
gather together young people from Bosnia-Herzegovina through recreation and friendship, care for cultural creative work and the preservation of existing cultural and political consciousness about belonging to their own nation for refugees, children and their mothers, and also relatives and friends who live in Slovenia. (Cultural Weekend for Children 1994, quoted in Pesek 1996: 258)

Hence, Vali was primarily an organised platform for coping with exile. In her ethnomusicological writings, Andree Zaimović nonetheless depicts the performing of sevdalinkas as an emotional musical choice of refugees, without properly discussing the organisational aspects of their adoption in various refugee communities. This embracing of the sevdalinka appears as an outcome of identification, understood as a profound reaction of the "people", ignoring that identification can be organised by various agents and power relations.

Thus I was a witness to the process of making a strong musical and cultural identity of young people who went into exile mostly from an urban background. This identity contained not only various genres of popular music, as is common for young people of this socio-cultural milieu, but also an affinity with the Bosnian-Herzegovinian musical tradition. (Andree Zaimović 2003: 4)

For [my] work, the autochthonous Bosnian-Herzegovinian melodic-poetic form the sevdalinka is particularly important, because it resounds with the greatest part of the Bosnian-Herzegovinian diasporic population. This is because of a series of characteristics contained in this form, thanks to which the sevdalinka becomes an irreplaceable identification symbol. (Andree Zaimović 2003: 55)

Taking up the sevdalinka was thus not only an emotional choice of the "refugees"; 6 there is also something inherent in this music form, "a series of characteristics", that stimulated refugees to respond to its qualities and adopt it. According to this author, with its urban and multicultural background and lyrical expression of love and passion, it was "a paradigm of an ideal Bosnia" (2003: 92) and thus an inevitable symbol grasped by the heterogeneous population of war refugees, irrespective of age, gender, education, ethnicity or urban/rural background. As an identity symbol and cultural value, it was allegedly irresistible for the "refugees". Note: the author refers to a community or a collective, which we would like to question.

\footnotetext{
${ }^{6}$ Adelaida Reyes cautions that one should consider what a "refugee" exactly means, since refugees usually find themselves in asymmetrical power relations with refugee camp authorities, their country of origin, agents of the host country etc., which affects the conditions within which "musical life is shaped and reshaped" (1999: 208).
} 
Andree Zaimović was not the first, nor the only ethnomusicologist to refer to the collective identity to explain why refugees took up a particular musical form. In fact, she embraced prominent academic discourse. When, following Adelaide Reyes $(1986,1989)$, ethnomusicologists started to work with refugees and their musical lives in a systematic manner, treating traditional or culturally distinguished music as an anchor for refugee identity became salient. ${ }^{7}$ In his work on Afghan refugees, John Baily $(1999,2005)$ traces forms of music that were transplanted from Afghanistan to other countries and points to some as providers of cultural identity and as therapeutic experiences at the individual and community levels. Jaap Orth mentions Oksana ZharinovaSanderson's music therapy for refugees, based on the use of "(folk)songs known by her clients from their own cultural heritage, in order to share memories and thoughts from their native countries and to strengthen their own identity" (2005: n.p.). He himself sees music therapy for refugees as follows: "Keeping and developing people's cultural identity and their orientation according to the culture of their native country. Listening to and playing the music of their own country stimulates the experience of their culture" (Orth 2005: n.p.). Svanibor Pettan $(1995,1996,2009)$ presents the case of an applied ethnomusicology project in Norway, where, following Kjell Skyllstad, he designed a framework for the musical empowerment of $\mathrm{BH}$ refugees and to bring them closer to the host society. However, while admitting that refugee identity building was a planned process, he nevertheless presupposes that the sevdalinka is a collective heritage of a heterogeneous refugee population. Dimitrije Golemović followed the same line of interpretation in his analysis of music-making among Bosnian refugees in Slovenia and Serbia (2002). Researchers on the sevdalinka in Austria, too, claimed, "for the performers as well as for Bosnian audiences in Vienna, this music brings back memories of their homeland and therefore seems to be a very important part of their musical identity" (Hemetek et al. 2007: 141). Furthermore, considering a group of musician-vocalists active in one of the refugee centres in Ljubljana in the 1990s, the Slovenian folklorist Marko Terseglav clearly mentions that they were animated by an enthusiastic refugee whose aim was to keep the $\mathrm{BH}$ heritage alive, but concludes that "music and singing among Bosnian refugees in Slovenia was not stimulated from the outside, but came out as an inner need and necessity", since "folk spiritual culture or folk music proves to be the only tangible remains of the broken ethnicity and its culture", which thus helps refugees "to survive the worst moments, and at the same time helps them to maintain their own cultural and ethnic identity in a strange [...] environment" (Terseglav 2001: 260).

\footnotetext{
${ }^{7}$ It is rare to encounter statements that a blues piece planted the seed for research on music making in exile, as Keila Diehl puts it (2002: xix), or to find attentiveness to such a variety of forms of music as in her study of Tibetan refugees in India.
} 
What is striking is that these writings take the relation between music and collective/personal identification as a given, rather than as established through contingencies and various organised projects that aim to aid refugees cope with exile. Researchers approach the issue as if there is no doubt that certain musical forms are woven into identities, without considering them as also learned in the traumatic experience of exile. We think that this approach to the revival of the sevdalinka in exile is an oversimplification.

\section{EXPERIENCING THE SEVDALINKA BEFORE AND DURING EXILE}

It certainly makes sense to connect refugees' performing of sevdalinkas with their experiences growing up in $\mathrm{BH}$ and their longing for home. Alan Lomax already proposed that

the primary effect of music is to give the listener a feeling of security, for it symbolizes the place where he [sic] was born, his earliest childhood satisfactions, his religious experience, his pleasure in community doings, his courtship and his work - any or all of these personality-shaping experiences. (1959: 929)

In $\mathrm{BH}$, the sevdalinka in various forms and with various connotations ${ }^{8}$ is a major part of private and public soundscapes, and as such, many people internalise it. Hence, it is not entirely wrong to say that for many refugees this music holds a memory of home and performing it is a way of coping with loss and uncertainty. However, let us take a closer look at some of the performers' experiences.

Hazemina Đonlić, a member of Vali, an accordion player, singer, a student of musicology and a music pedagogue, explained in her interview that it was because of her father, a self-taught musician from Gradačac, that she "at a very early age recognised a big part of the archive of ethno music". Besides listening to his playing and learning from him, radio and cassette recordings of "newly composed folk music", ${ }^{9}$ which may also refer to the sevdalinka (cf. Rasmussen 2002), filled her home environment. Therefore, while she was a

\footnotetext{
${ }^{8}$ Marko Terseglav depicts diverse perceptions of the sevdalinka among the participants of the music group that he worked with. Some were more inclined towards the "classical" radio format, others towards forms popularised by the contemporary mass media (2001: 259). The question "what is the sevdalinka?" (Karača 2001), which means what connects its various forms and should they all be considered "proper" sevdalinkas, has been quite vivid in debates in post-war BH. During our fieldwork in Sarajevo in May 2014 we have thus encountered various explanations by musicians and researchers with regard to this question.

9 The so-called "newly composed folk music" is a hybrid folk-based musical genre developed and commercialised in the context of rapid modernisation of the post-war Yugoslavia (see Rasmussen 2002).
} 
refugee, performing the sevdalinkas was an intimate experience of remembrance, longing and loss. However, in the book Ten Years of Solitude, depicting her exile in Slovenia, she introduces the activities of Vali as an endeavour to sustain Bosnian cultural identity (2003: 43), thus inscribing her reflections on the sevdalinka in exile into the discourse of the aforementioned ethnomusicologists. Nevertheless, in the interview she draws our attention to her acquaintance with a wide variety of individual involvements with the sevdalinka before, during and after exile, indicating that she is not prone to overgeneralisations of the "identity response". As a music pedagogue, she was involved in the musical education of refugee children, ${ }^{10}$ for whom music was something they were learning and not something they already identified with. However, the same could also be argued in the case of the adults, who not only responded to music, but also learned it anew. Her rich musical experiences in exile are themselves an evident example of the heterogeneity of music practices that existed in exile, as well as an important argument that "identity" is not an adequate explanation of why the sevdalinka is performed.

Nevertheless, Hazemina Đonlićs account of the emotions evoked by the sevdalinka should not be dismissed as trivial. A feeling of intimacy stimulated by the sevdalinka was also persistent in the life of Maida Džinić Poljak, a singer in the group Dertum. For her, too, the sevdalinka activates pleasant memories of home. She remembers that in BH the so-called sjela, socialising events where people meet and eat, are always inseparably connected with singing. In her interview, she emphasised that, as a little girl, the most beautiful thing was to sit with her parents and their guests and listen to their singing:

In most houses in Bosnia, the sevda $h^{11}$ was sung. Always when people sit they sing the sevdah. My mother, father, her sisters, brothers, his brothers, sisters, the entire family, someone plays an instrument, I don't know, a clarinet, a guitar, an accordion, everyone something, however, nobody from this generation ever went to music school, nothing, nor even to singing classes, nor thought of it as something that could be made into a business. It's for the soul. When I was little, it was one of the most beautiful things in the world when I was allowed to sit in the evening with them and listen. This is merak, ${ }^{12}$ it's for the soul.

${ }^{10}$ She collaborated with the Slovenian musician-songwriter Etbin Štefančič, whose teaching was based on Orff instruments. Among several compositions that he prepared for classes in refugee centres were also sevdalinkas. In conversation, he explained that he used to work as a DJ at the alternative radio station, Radio Student Ljubljana, where already decades ago they produced a broadcast on "forms of ethnic music". Thus, he became acquainted with various "traditional forms", including the sevdalinka.

${ }^{11}$ In this case, the word refers to the sevdalinka as a song. In general, however, the word refers to the feelings of unrequited love and love's yearning, passion, intense longing, melancholy and spleen (Pennanen 2010: 78), which can also be expressed by or stimulated through performance of the sevdalinka.

${ }^{12}$ A Bosnian word for pleasure. 
However, not all the members of Dertum had the same attitude towards the sevdalinka. The guitarist Erol Hadžimušović recalled his quite different experience. He told us that you cannot escape from it in $\mathrm{BH}$, since you will hear it always and everywhere in the public realm, which can be more annoying than pleasing. Besides, contrary to some perceptions, in BH the sevdalinka was not an integral part of each and every home. Vesna Andree Zaimović and her sister Marina Andree also note this. In Marina's documentary Sevdah (Andree 2009), they explain that the sevdalinka was not part of their childhood. Moreover, (Yugoslavian) rock and punk provided much of the intimate soundtrack for young people growing up in the eighties, and many young people regarded traditional or tradition-like music as backward. The importance of (Yugoslavian) rock music lasted after the breakup of Yugoslavia and accompanied many young people into their forced migration. For example, in the refugee centre in the Slovenian town of Ilirska Bistrica, youngsters formed a punk-rock group called Nešto između [Something In Between], which focused on electrically amplified sounds during its entire existence (see Kozorog in print). Rehearsing at the Vodnik Manor House, the band Centralno grijanje [Central Heating] followed a similar path. Obviously, (young) refugees did not embrace the sevdalinka as a rule.

Vali, too, started as a music group performing pop and rock hits and not sevdalinkas (Đonlić 2003: 43). The ensemble functioned as a space for young refugees to socialise and share experiences, and as such sought to attract them with their own music idioms. At that time, pop rock was certainly more alluring to that generation than the sevdalinka, which was incorporated in the course of time. ${ }^{13}$ Some of the members of Vali recall that they were more or less ignorant of the sevdalinka until their involvement in the group, and thus adopted it among their musical preferences only after leaving $\mathrm{BH}$.

The stories so far may convince us that the sevdalinka was not an indispensable choice for refugees' coping with uncertainty in the foreign environment. Domestic soundscapes, both private and public, indeed stimulated longing for home when persons were unwillingly displaced. However, refugees had different attitudes towards sevdalinkas before exile, if any at all. This is why we should not dwell exclusively on emotional and identitybased explanations of the popularity of the sevdalinka in exile. We therefore rather argue that its playing was to a great extent an organised activity for which individual and institutional agents were crucial. Moreover, as we will show below, it was more the reaction of the Slovenian audience than of the

${ }^{13}$ Đonlić presents the following repertoire of their most frequently performed pieces: patriotic songs (Sva bol svijeta; Raskrsnice; Help Bosnia now; Sviraj mi, sviraj brate; Mostarska; Pismo prijatelju; Sarajevo će biti), legendary ex-Yugoslavian hits (U svemu naj; Good bye teens; Nekako s proljeća), foreign popular songs (Stand by me; Help!; Let it be), folk songs ( $S$ one strane Plive), and Slovenian pop songs (Zarjavele trobente; Dan ljubezni) (2003: 43). 
Bosnian diaspora in Slovenia that convinced young musicians to focus on this musical form, which was highly marginalised in Slovenia during the time of Yugoslavia. Nevertheless, its identity dimension cannot be completely denied. Thus, we will now turn to the question of whose identity was in fact affected and why. In relation to the sevdalinka in Slovenia, we would rather refer to identity building than to a spontaneous identity process.

\section{THE QUEST FOR IDENTITY}

Let us return to the work of Andree Zaimović and other applied ethnomusicologists working with refugees at that time..$^{14}$ One of the prominent ideas behind the work of Svanibor Pettan, Ursula Hemetek and others who actively engaged with the refugees from the BH war was that the refugees' self esteem was low, but "their" music, if accepted and admired by their hosts, could empower them and bridge the gap between different cultural backgrounds. They therefore helped refugees start searching for their "own" musical traditions and to establish ensembles, which have performed with and for the members of the host society, enabling them to have a more active role in the new environments. The work of these ethnomusicologists was precious, since they helped refugees discover music as a source of empowerment (cf. Hemetek 2006) and as a means of improving relationships among people (Pettan 1995, 1996, 2009). Nevertheless, their mission was also responsible and risky, since they acted as professionals who selected the representative musical forms and styles among many possible ones that refugees "brought" into exile (cf. Pettan 1996: 250-251); they thus actively established which would be the "essential" one(s). The peril of their scholarly work was that they might contribute to the musical essentialisation of their homeland heritage and, moreover, might convince a certain "refugee population" that a specific kind of music represented them, thus conveying the expectation that they identify with it. But was this kind of "strategic essentialism" (Butler in Hofman 2010: 24) perhaps necessary in order to find the means to connect ethnically divided BH refugees (and their hosts)? Perhaps so, but perhaps restricting themselves to organising the conditions for socialising and making whatever kind of music the refugees themselves chose to play could have been another, less intervening option (as we will show with examples below).

${ }^{14}$ Klisala Harrison (2012) presents various epistemologies that, in recent decades, have emerged in the broader field of applied ethnomusicology. They are diverse in their conceptual and discursive approach to research and practice. She proposes the concept of "epistemic community" to distinguish between epistemologies and related practitioners/participants. With regard to the work with refugees from $\mathrm{BH}$, her proposition seems adequate. 
The applied ethnomusicology of Andree Zaimović should be regarded as a specific case, since her involvement in refugee music-making is different from the work of other scholars. First of all, she was not involved as an ethnomusicologist in the work with refugees, but went into applied ethnomusicology only at a later stage (2003: 11). She was involved as a "cultural immigrant", as an intellectual with a responsibility to help co-refugees acquire musical education, dignity and hope. Artists, cultural workers, journalists etc. were better situated as refugees in Slovenia, since many of them already had a circle of friends there from the time before the war. Her endeavours were thus to help refugees who had substantially less social capital and found themselves in a difficult situation:

The traumatic experiences of the refugees, caused by the organized violence in their homes, forced deportations, the disruption of a deeply rooted way of life and separation from their original social surroundings, were not resolved in exile. In fact, the collective refugee camps organized as a ghetto in which there was no privacy and no everyday responsibilities, together with the refugees' inability to acquire work visas, which forced them to live at the existential minimum, destroyed optimism and marginalized the identity that each person had acquired over the years. (Andree Zaimović 2001: 111-112)

Notwithstanding, her attentiveness to personal traumas takes on a different spin in her analysis. Namely, the author instantly transmutes a personal identity, which was recognised as suffering, damaged and in need of help, into a collective identity. Or more precisely, collective identity is proclaimed as the cure for personal identity and the sevdalinka as a musical means to achieve this goal. There are several reasons for this abrupt turn. First, the author's basic subject is music, which is commonly perceived as a collective experience and practice. She quotes Simon Frith's statement that music "seems to be a key to identity because it offers, so intensely, a sense of both self and others, of the subjective and collective" in support of her thesis (2001: 113). Besides, the author worked with refugees during the times of fierce violence in $\mathrm{BH}$ and when the new state of $\mathrm{BH}$ was emerging. In this period, the quest for national identity was strong in exile, too (Vrečer 2007: 126), and the sevdalinka functioned as "an authentic BH form, which is not characteristic of other republics of the former Yugoslavia", ${ }^{15}$ so it "confirms the cultural identity of BH, which at this delicate moment and in a very short period of time has had to replace the Yugoslavian national identity" (2001: 113-114). And there is another context, distinctive particularly for Slovenia, because it regards the economic immigrants or diaspora from BH in Slovenia, dating to

${ }^{15}$ This idea has been present in $\mathrm{BH}$, but related musical forms are also found in the neighbouring countries. 
the times of Yugoslavia, but also resonating when BH refugees sought exile. More specifically, the "Bosnians" had a low standing as backward industry workers in the Slovenian society in the period of the former Yugoslavia, and, at least since the 1980s, they were also the targets of xenophobic remarks (see Mežnarić 1986: 65-67). According to Andree Zaimović, this prejudice derived from immigrants' rural and secularised-Muslim background, the fear of which was growing at the beginning of the 1990s among average Slovenians because it threatened their "newly reinstated Middle-European orientation" (2001: 111). Refugee intellectuals therefore fought "against negative and incorrectly based stereotypes about the traditional and present culture of $\mathrm{BH}$ by presenting authentic cultural and therefore musical expression of BH" (2001: 112). In this context, the sevdalinka acquires another role as a collective identity builder, namely, its urban background (Karača 2005) is displayed to counter the negative images of the "ruralness" of Bosnian culture. Those who promoted the sevdalinka thus "propagated the urban spirit of BH" (2001: 114). This perception was in fact part of an urbo-centric discourse, persistent in $\mathrm{BH}$ and the wider Balkan context, that projected the blame for the war onto the rural population (see Brown 2001; Jansen 2005: 109-167). As Andree Zaimović later explains to the sevdalinka performer Damir Imamović, she also embraced this music form because she believed that rustic sentiments were endangering BH's urban spirit:

Before the war, I had nothing, absolutely nothing to do with the sevdalinka. It wasn't part of my family tradition. But during the war, when I was trying to prove that in $\mathrm{BH}$ we have a just cause, that it is not a civil war, that rural culture was fighting against urban culture, I realised that the sevdalinka is ideal proof of what I and others were fighting for. It was the paradigm of a refined urban Bosnia facing destruction by the war. I think that the song survived thanks to the people in diaspora, fighting their own inner battles far away. The sevdalinka became another argument: "This is who we are, this is our refined Bosnia, which they want to destroy." (Andree 2009)

The sevdalinka fits well into the idea of "authentic hybridity" (cf. Ballinger 2004), which promotes the idea of common, Bosnian identity that transcends ethnic divisions, but at the same time excludes the rural Other (Bartulović 2013). Moreover, it also corresponded well to the needs of those educated and engaged individuals who shaped the refugees' "Bosnian identity" in Slovenia and for whom it was important that the features of this identity were carefully selected to fit the 1990s "urban" or trendy taste of Slovenian, Bosnian and other people. In the realm of music, this "fitness" largely corresponded to "world music" trends, an inclination of "Western consumers" to get acquainted with non-Western musical forms. This musical trend was probably one of the most confirmative foundations for "Bosnian identity" 
thus conceived, since the sevdalinka was upheld as another still underappreciated musical jewel of the world (Andree Zaimović 2001: 115-118; 2003: 119-131; Terseglav 2001: 262-264). We will return to the context of "world music" later.

There is one important lesson we can learn from the work presented above, which also concerns the practice of applied ethnomusicology with refugees more generally. It is the lesson about how anti-essentialism turns into its opposite, when a particular musical form is identified as and proclaimed an emblem of a people. To overcome the ethnic divisions in BH exacerbated by nationalistic policies, Andree Zaimović refuses ethnicity as a possible gate into the future of $\mathrm{BH}$ and searches for an alternative. She was very right to claim that the people of BH have many things in common, despite the claims of ethnic distinctiveness by those in power. However, to prove her claim, she tried to define a common cultural identity, shared by all the ethnicities, religions, social backgrounds etc. (cf. Pettan 1996: 250-251). Quoting several writers (2003: 27-32), she defines the "Bosnian spirit" (bosanski duh) as a spiritual and mental characteristic of people from this part of the world and the sevdalinka as the carrier, quintessence and expression of this collectively shared genius. Needless to say, such conceptualisations of music can be instrumentalised precisely for the nationalistic purposes the author was fighting against.

\section{ASPECTS OF THE ORGANISED AND SPONTANEOUS EVOLUTION OF THE SEVDALINKA IN SLOVENIA}

As already mentioned, Andree Zaimović describes the sevdalinka in Slovenia as a spontaneously developing form, a result of refugees' feelings. In contrast to this interpretation, we have proposed that this very author was an important curator of the sevdalinka's revival in Slovenia. From this perspective, performing the sevdalinkas was not so much spontaneous as carefully organised. We do not deny that people also performed it ad hoc, e.g. when emotionally moved by immediate events, especially when the performers had a vital connection with this musical form (like some members of the aforementioned Vali and Dertum). However, there is another aspect of spontaneity we would like to clarify in this section, one that concerns young refugees' social life in Ljubljana.

Much of the life of refugees in Slovenia was managed by Slovenian government agencies, international aid and Slovenian, non-Slovenian and international nongovernmental and volunteer organisations. ${ }^{16}$ Given only

${ }^{16}$ For the role of institutions, see Đonlić (2003) and Vrečer (2007). 
partial solutions provided by Slovenian governmental organisations and insufficient response to their needs, refugees also started to organise certain activities themselves. The aforementioned Cultural Weekend for Children is an example in the area of cultural education of children and of youth's creative participation in leisure activities. Before the beginning of the programme, children and young refugees would "aimlessly wander around Ljubljana or live through quite monotonous days in refugee centres, where their only obligation was to wait in line for food and clean the corridors" (Đonlić 2003: 40). A group of music pedagogues, previously co-workers in the Ilidža music school in Sarajevo and their friends aimed to change this situation by arranging a room for creative activities in the Vodnik Manor House. More than one hundred children are reported to have frequented the programme already in the first months of 1993 (Đonlić 2003: 41). Their activities were diverse: musical education, fine arts and literary workshops, choir singing, artistic copper crafting etc. Audio- and videocassettes and books, including the package Sarajevo će biti [Sarajevo will be], were issued. The workshop mentors planned a bicultural education by including both $\mathrm{BH}$ and Slovenian cultural works in the programme. They also formed the aforementioned "folk orchestra", an ensemble devoted to folklore, particularly the sevdalinka (Đonlić 2003: 43).

Vali was formed in the same refugee environment. The first time the group performed as Vali was in February 1994 at the celebration of the Slovenian poet Valentin Vodnik's birthday, after whom the Vodnik Manor House was named. As already mentioned, in contrast to the "folk orchestra", Vali was inclined towards pop-rock music. Referring to Terseglav's hypothesis that music is the rare part of a culture that cannot be taken away from people and that refugees thus inevitably seize upon it (2001), Hazemina Đonlić comments that it is quite surprising that Vali did not take recourse to tradition already at the beginning of its career, but "only in the last years" (2003: 43). She then states that it is Vesna Andree Zaimović who can be largely credited for the fact that the group turned to traditional songs, not in a "traditional way" of performing them, but by adding new rhythms and melodies that are more beloved by young people. Moreover, the group's choir singing was itself an innovation in performing the sevdalinka. The group thus reinterpreted not only sevdalinkas, but also Sephardic and Roma songs.

An important question arises here: what role did the "world music" trend of the 1990s have in this turning point in Vali's career? We by no means want to claim that turning points in music careers should be understood as events, but rather as evolutions, and therefore they cannot be reduced to unilateral causes, but should be perceived as multi-layered processes. Moreover, it is quite a challenge to find out what factors were important for Vali two decades ago. However, we can be certain that "world music" was important in this 
case; Andree Zaimović, too, ascribes a major role to it in Vali's career (2003: 119-131). This is also clear from Vali's collaboration with Vlado Kreslin, a leading figure in the Slovenian rock music scene, who in the 1990s turned to the ethno-rock style.

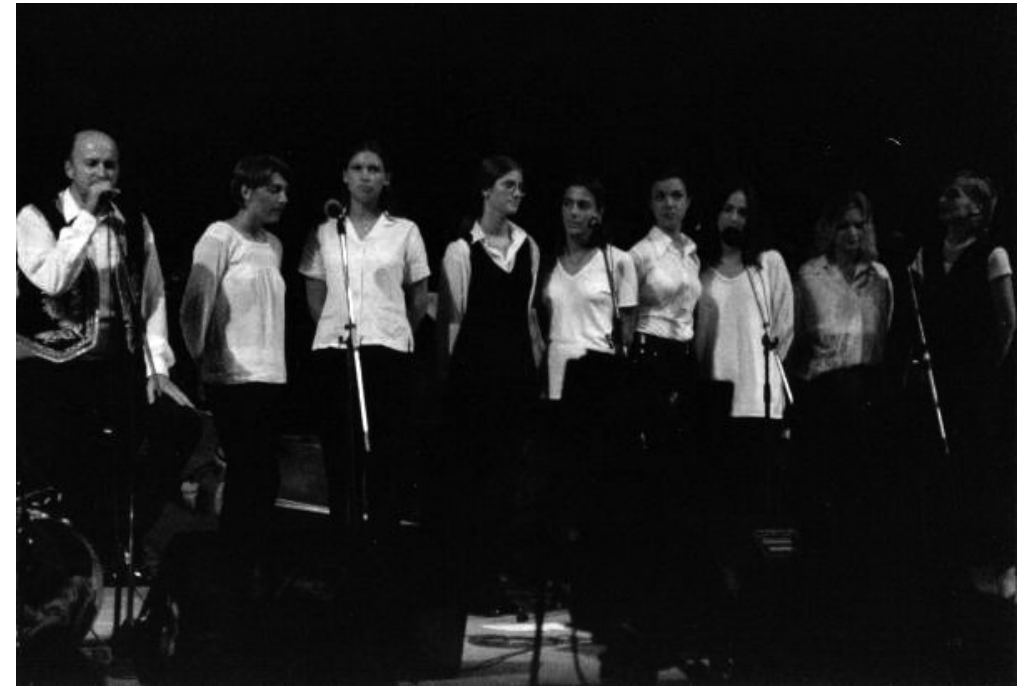

Vali and Vlado Kreslin in 1996 (photo: Egon Kaše)

It is important to note that, in contrast to other constituent republics of Yugoslavia (cf. Petrović 2013), Slovenia had almost no experience with the sevdalinka before the 1990s, except within the curtained worlds of the $\mathrm{BH}$ diaspora. ${ }^{17}$ Nevertheless, men serving in the army in various parts of the country and musicians who collaborated across its republics were more or less acquainted with one or the other of its forms. Vlado Kreslin certainly came across it already before the war, and according to a member of the group, his admiration for the sevdalinka was genuine..$^{18}$ Vali and the Slovenian musician started with three widely recognised songs, later expanding their repertoire to five sevdalinkas and one Sephardic song from BH. In 1997, three pieces were released on the CD All equal?,19 which was distributed free of charge, financed by the Office of the Republic of Slovenia for Youth; and in

${ }^{17}$ A few exceptions can be mentioned, e.g. an arrangement for the national big band by Jože Privšek, a trumpet piece by Petar Ugrin, references in compositions by Alojz Ajdič etc. We want to thank Ognjen Tvrtković for pointing this out to us.

${ }^{18} \mathrm{His}$ wife's role in his collaboration with Vali should not be overlooked, since she was the representative of the Slovenian volunteer organisation Most, which was then intensely involved in working with refugees.

${ }^{19}$ The title was a paraphrase of the "All different - all equal" international campaign, which promoted tolerance. 
1998, all six songs were released on Vlado Kreslin's commercial CD Muzika. In this project, Andree Zaimović, who describes herself as "the initiator and manager of this project, as well as the composer of the arrangements of all six of the songs" (2003: 122), and Kreslin communicated in a common language of "world music", in which several Slovenian music enthusiasts were fluent at that time.$^{20}$ It was also crucial that one of the nationally most successful performers popularised the sevdalinka in Slovenia; for a while, he brought Vali into the Slovenian popular music mainstream. Of course, these facts make it clear that Vali's evolution was not spontaneous, but reflected its core members' "world music" and "national rock star" contexts. To conclude, it is indeed pleasing that the route they had taken helped some young refugees launch their music careers or simply spend valuable time in Vali, but that does not provide justification for the initiator of the project to alienate its core product, the sevdalinka, and explain it as a primordial search for identity, without placing it in its context.

There were various parallels between Vali and Dertum, including their focus on "world music", but the two groups' careers varied immensely as well. To a certain degree, they inspired one another, but they belonged to very different and in many ways separate music milieus. Nevertheless, Farah Tahirbegović, one of the singers in Dertum, was central to both groups and was very likely also the one who provided an ideological basis for the sevdalinka's revival in Slovenia. As a poet and writer, she was active at the Vodnik Manor House, where, already before Dertum's beginnings in 1995, she had published a book of short stories, Pismo roditeljima (A letter to my parents) (1994). In the sevdalinka, she recognised something very precious from $\mathrm{BH}$ culture that could become a source of refugees' empowerment and the means for improving relationships among people, as Andree Zaimović later commented (Andree 2009). She adds: "[Farah] implanted love for the sevdalinka in me. She opened the door of the sevdalinka to me." Thus, the revival was the result of the imagination and hard work of a few refugees, Farah and Vesna in particular.

However, the case of Dertum points to another aspect of spontaneity in the process of the sevdalinka's blossoming in 1990s Slovenia: the young and "alternative music" audience, gathering in small youth clubs, who seized

${ }^{20}$ The Druga Godba festival in Ljubljana, taking place since 1984, was an important incentive to engage in "world music" in Slovenia. A few members of Dertum have told us that it was influential in their music-making. Andree Zaimović reports an interesting detail from this festival in 1994, when the Austrian group Wiener Tschuschenkapelle performed a number of sevdalinkas as a political statement, referring to the war-torn country (2003: 120-121). This was probably also one of the very first interpretations of a sevdalinka in the context of "world music". Marjan Stanić, the percussionist of Dertum, himself not a refugee, has told us that he owned a cassette by this same group, which had so impressed him that he began trying to persuade his fellow musicians from BH to transform from a rock-oriented band called Durum into the "world music"-oriented Dertum (we will examine this transformation below). 
upon Dertum's version of the sevdalinka and co-created conditions for its thriving in Slovenia. In contrast to Vali, Dertum was not externally organised and guided by a professional music pedagogue. It started as a secondary school five-member male band, called Durum, which initially performed ex-Yugoslavian rock music, mostly at "Balkan parties" in Ljubljana. ${ }^{21}$ The band was not composed entirely of refugees, although the residence of some members in the refugee centre at Šmartinska Street in Ljubljana was significant for the band's career. More specifically, there they co-resided with Farah Tahirbegović, without whom a teenage male rock formation would probably never have become the mixed-sex Dertum performing sevdalinkas. Our ethnographic material on Dertum indicates that teenage male musicians were inclined towards having fun and forgetting it all by merely playing instruments. Only more mature reflection by elder female counterparts, Maida Džinić Poljak among them, led to more organised performance and awareness that music can have a political message as well. ${ }^{22}$ This emerged when the group joined the Exiles project [Pregnanci], which was supported by the KUD France Prešeren cultural centre in Ljubljana and which aimed to break open the cultural ghettos of the refugee centres and enable refugees to creatively participate as part of Slovenian society. ${ }^{23}$ KUD, which in the late 1980s became a well-known meeting place for youth and a venue for alternative concerts, exhibitions and theatre plays, gradually became the institutional background for Dertum, involving it in its various projects, e.g. its political theatre. ${ }^{24}$

Dertum's turn to the sevdalinka was thus partly stimulated by a few people whose motives varied from emotional attachment to domestic soundscapes to pragmatic affiliation with "world music", a political response to war, the needs of the theatre and through the persuasion of the Exiles project managers. However, as Gregor Belušič, Dertum's sound engineer and saz player (himself not a refugee) recalls, the sevdalinka became trendy oriental rhythms and melodies for the young to dance to: "KUD was simply a nest of Ljubljana city slickers who loved folk music, and Dertum fell into it like a fly into honey." ${ }^{25}$ It was not the "refugees" or the BH diaspora that convinced the

${ }^{21}$ These parties were organised in clubs in the early 1990s. Initially, they functioned as an alternative to and in defiance of the national divisions emerging through the breakup of Yugoslavia, but they were soon commercialised (Ceglar 1999; Stankovič 1999).

${ }^{22}$ Members have different memories; e.g. the percussionist quoted above, Marjan Stanić, hinted that young men had their own aspirations and were not merely led by older female counterparts.

${ }^{23}$ Part of this support came from the aforementioned musical pedagogy of Hazemina Đonlić and the Orff orchestra led by Etbin Štefančič, which won the silver Prize of Europe in 1994.

${ }^{24}$ Dertum composed music for two theatre pieces, Dođi makar sebi, ako nemaš kome drugom (1995) and I mirna Bosna (1997). The music was experimental, but with references to the sevdalinka.

${ }^{25}$ Omer Pobrić, a sevdalinka composer and performer and one of the most important figures of its revival in BH during and after the war, performed in KUD in the mid-1990s. He demonstrated an affinity 
musicians to keep on working on the sevdalinka, but rather the reaction of young Slovenians in "alternative music" clubs, ${ }^{26}$ who simply went crazy over Dertum's unconventional style of playing traditional forms from different parts of ex-Yugoslavia, using atypical instruments like guitars, adding jazz and rock rhythms and speeding up the tempo.

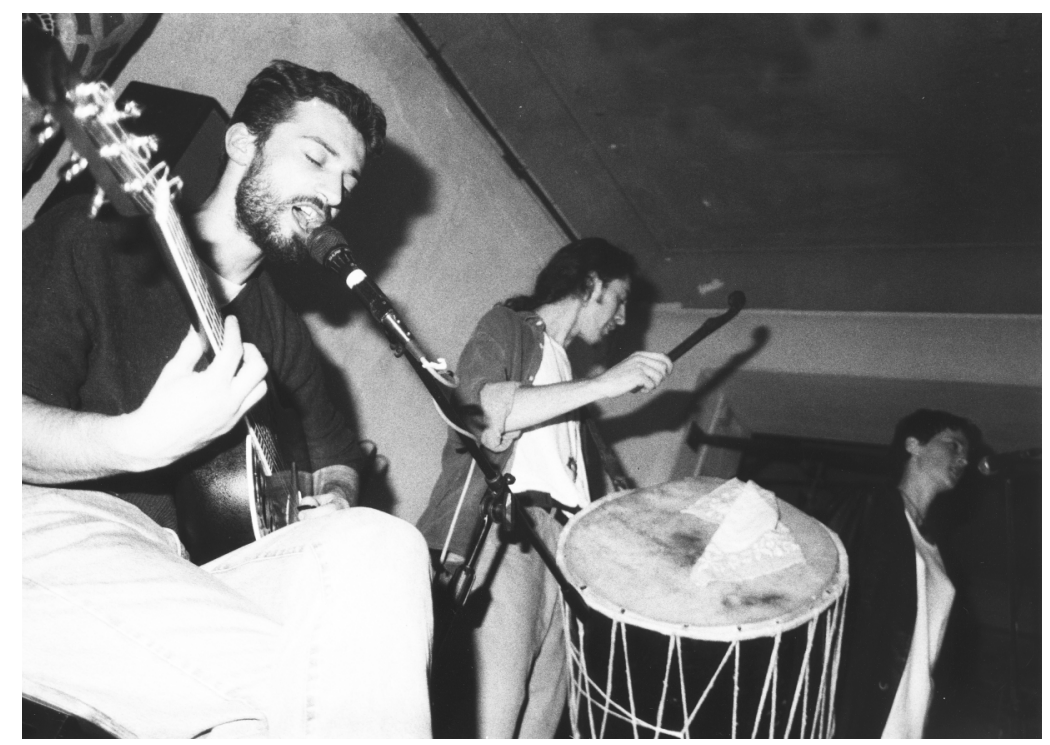

Dertum (photo: Arhiv KUD France Prešeren)

As Dertum's guitarist Erol Hadžimušović explains, the demands of the audience were in fact the most fundamental reason why the band turned to traditional forms, among which the sevdalinka was outstanding. As he explains, they started by chance with three sevdalinka pieces at an exhibition dedicated to $\mathrm{BH}$. At the same event, they were invited to regularly play ex-Yugoslavian traditional music in an inn with an ex-Yugoslavian motif, so they prepared a repertoire including a few sevdalinkas. But, surprised by the audience's passionate response, they realised that the sevdalinka and related songs from Macedonia could be the path to their band's success. To make it clear, for its members, the band was not only a provider of emotional shelter, but also always a small but steady source of income. ${ }^{27}$ Although the group

with Dertum and encouraged their endeavours.

${ }^{26}$ Dertum was in fact closely connected with the alternative music milieu, since both Belušič and Stanić were members of the avant-garde rock formation Žoambo Žoet Workestrao, while Belušič was an active participant in various underground venues.

${ }^{27}$ One of the laws most harmful to BH refugees in Slovenia was the ban on their employment, which in many cases resulted in poverty (Vrečer 2007). 
became part of the Exiles project, and thus played in numerous refugee centres around Slovenia in its framework, Erol is clear about the band's core audience: "Our people came too, to hear it. OK, we were in a way a reminder of their country, of their environment, of what they'd listened to before. [...] But there were more Slovenian guests at our concerts." The band's success was therefore largely connected with its popularity in youth venues around the country. In 1996, one such concert in KUD was recorded and, in 1997, released on a CD. It later gained cult status in a specific Slovenian alternative music milieu. The CD not only had an impact on the young Slovenian audience, but also influenced some of the young musicians in BH, e.g. Damir Imamović, to experiment further with the sevdalinka.

One aspect unrelated to the "world music" context was crucial: Dertum and Vali performed for an audience eager to hear music from places that they felt had been part of their homeland but that the course of history had taken away from them. This feeling may be called "Yugonostalgia", or "becoming adults in a nation state, but remembering a multinational and multicultural state", or perhaps "realising that something beautiful and precious is now (geographically) farther away than it recently was", but the fact is that many (young) people in Slovenia listened to traditional songs from various parts of ex-Yugoslavia with a special intensity and emotional investment. Our interlocutors, Slovenian fans of Dertum, thus repeatedly explained that they used to despise all kinds of traditional music from the other constituent republics of Yugoslavia - until Dertum changed their perspectives. This was possible because the band knew how to make such music attractive for an audience that had not grown up with it, but it was also possible because this audience opened its ears to musical forms whose status the breakup of Yugoslavia had redefined within the old (and new) national contexts.

\section{CONCLUSION}

The sevdalinka certainly marked the precarious lives of Bosnian and Herzegovinian refugees in Slovenia during the war and throughout the 1990s. In this article, we emphasise that its performing was not only spontaneous, but also largely (institutionally) organised. Moreover, its impact and role varied immensely. For some people, it was a means of coping with severe losses, for others it was a tool to change the social status and perception of "Bosnians" in Slovenia, influencing the dominant hierarchies of native and foreign culture. The latter emphasised the connecting nature of the sevdalinka, its "Bosnian spirit", which may confirm the common Bosnian (urban) culture that transcends ethnic boundaries. Nevertheless, most people involved in music-making presented here did not think about the ideological aspects of 
the genre, but just enjoyed playing music; being active and appreciated in the new environment was crucial for persons involved in both of the music groups analysed here. In Slovenia, the sevdalinka has thus evolved through an amalgam of memories, affects, motives, interests, reactions, counterreactions, identifications etc.

Vali and Dertum were unusual for Slovenia, but had a broad public impact: Vali communicated the sevdalinka within a "mainstream" and Dertum within an "alternative" music milieu. Although ethnomusicologists did not assist their endeavours, in a way they were related to Pettan's applied ethnomusicological project Azra in Norway (2005, 2006, 2009), first, because traces of a strategic essentialisation of music were present, and second, because the two groups managed to musically connect refugees with their host environment. However, when comparing Norway and Slovenia, John Baily's remarks on Afghan refugees in Peshawar (Pakistan), Mashhad (Iran) and Fremont (USA) are instructive. He suggests that geographical distance between countries of origin and settlement, and cultural similarity in terms of language, religion and other attributes (1999, 2005: 213), are relevant in the dynamics between local musical life and refugees' music-making. It seems that the geographical, but especially historical closeness between $\mathrm{BH}$ and Slovenia contributed much to the reinvigoration of the sevdalinka in Slovenia during the 1990s.

Vali and Dertum were probably also among the first to turn the sevdalinka into "world music", thus contributing to its reinterpreting revival in a more general perspective not restricted to Slovenia. Being in exile was significant for the involved musicians, since the judgement of the audience and reviewers was not as harsh as it might be in a "domestic environment" (cf. Baily 2005: 231), where evaluating performances of the sevdalinka has gradually become deeply marked by nationalist ideology. Nevertheless, besides their playful approach to rhythms and melodies, which were not ideologically supervised, the quest for (national) identity was intensely pursued also in exile, at least by some of the agents involved.

In this article, we have paid special attention to the pedagogical and theoretical work of Vesna Andree Zaimović. We decided to do so because of her prominent role in the described musical revival process in Ljubljana in the 1990s. Moreover, she linked her own work with the paradigm of applied ethnomusicology, i.e. with the ethnomusicological work with refugees, and thus unwittingly revealed some of its pitfalls, as well. More specifically, musically empowering refugees by teaching them the values of specific music traditions has become a frequent approach in applied ethnomusicology, yet taking certain forms of music as an indispensable part of refugees' backgrounds, life worlds and identities is problematic (see Hofman 2010). Instead of showing the often central role researchers play in making specific music a 
core value for refugees, which requires the organised learning of this music, authors are prone to propose that musical forms are woven into identities. As a result, the atomised ontology of different forms of music in refugee and host environments remains under-researched. What we set out to show, however, is not only that this results in profuse production of superficial reports on identity-driven music making, but also, and more importantly, that this helps reconstruct the mosaic of national identity symbols. Refugees have not "brought" the sevdalinka to Slovenia and seized upon it merely in response to trauma; rather, a whole set of musical tastes and life worlds has come together in exile, and one of the paths of music making - entailing the politicisation of music - has also led to the revival of the sevdalinka.

\section{REFERENCES AND SOURCES}

Andree, Marina. 2009. Sevdah. Studio Dim. DVD.

Andree Zaimović, Vesna. 2001. "Bosnian Traditional Urban Song 'On the Sunny Side of the Alps'. From the Expression of Nostalgia to a New Ethnic Music in Slovene Culture". In $\mathrm{Mu}-$ sic and Minorities. Svanibor Pettan, Adelaida Reyes and Maša Komavec, eds. Ljubljana: Založba ZRC, ZRC SAZU, 111-120.

Andree Zaimović, Vesna. 2003. Muzički izrazi bosanske dijaspore u zapadnoevropskoj kulturi. [Master thesis]. Sarajevo: University of Sarajevo.

Baily, John. 1999. "Music and Refugee Lives. Afghans in Eastern Iran and California”. Forced Migration. December, 10-13.

Baily, John. 2005. “So Near, So Far. Kabul's Music in Exile”. Ethnomusicology Forum 14/2: 213233. [http://dx.doi.org/10.1080/17411910500329658]

Ballinger, Pamela. 2004. "Authentic Hybrids' in the Balkan Borderlands". Current Anthropology 45/1: 31-60. [http://dx.doi.org/10.1086/379633]

Bartulović, Alenka. 2013. "Nismo vaši!" Antinacionalizem v povojnem Sarajevu. Ljubljana: Znanstvena založba Filozofske fakultete, Zupaničeva knjižnica.

Brown, Keith S. 2001."Beyond Ethnicity. The Politics of Urban Nostalgia in Modern Macedonia". Journal of Mediterranean Studies 11/2: 417-442.

Ceglar, Miha. 1999. "Balkan scena”. In Urbana plemena - subkulture na Slovenskem v devedtdesetih. Peter Stankovič, Gregor Tomc and Mitja Velikonja, eds. Ljubljana: Študentska založba, 75-82.

Diehl, Keila. 2002. Echoes from Dharamsala. Music in the Life of a Tibetan Refugee Community. Berkeley, Los Angeles, London: University of California Press. [http://dx.doi.org/10.1525/ california/9780520230439.001.0001]

Đonlić, Hazemina. 2003. Deset let samote. Izkušnje bosansko-hercegovskih begunk in beguncev v Sloveniji. Ljubljana: Društvo Kulturni vikend.

Golemović, Dimirije 0. 2002. "Tradicionalna narodna pesma kao simbol novog kulturnog identiteta. (na primeru prakse jugoslovenskih ratnih izbeglica)". Novi zvuk-internacionaIni časopis za muziku 19: 57-65.

Harrison, Klisala. 2012. "Epistemologies of Applied Ethnomusicology". Ethnomusicology 56/3: 505-529. [http://dx.doi.org/10.5406/ethnomusicology.56.3.0505] 
Hemetek, Ursula. 2006. "Applied Ethnomusicology in the Process of the Political Recognition of a Minority. A Case Study of the Austrian Roma". Yearbook for Traditional Music 38: $35-57$.

Hemetek, Ursula and Sofija Bajrektarević. 2000. Bosnische Musik in Österreich. Klänge einer bedrohten Harmonie. Vienna: Institut für Volksmusikforschung und Ethnomusikologie.

Hemetek, Ursula, Hande Sağlam and Sofija Bajrektarević. 2007. "Documentation of the Concert 'Unexpected Viennese Musical Worlds' (Wiener musikalische Welten der anderen Art)". In Cultural Diversity in the Urban Area. Explorations in Urban Ethnomusicology. Ursula Hemetek and Adelaida Reyes, eds. Vienna: Institut für Volksmusikforschung und Ethnomusikologie, 137-147.

Hofman, Ana. 2010. "Maintaining the Distance, Othering the Subaltern. Rethinking Ethnomusicologists' Engagement in Advocacy and Social Justice". In Applied Ethnomusicology. Historical and Contemporary Approaches. Klisala Harrison, Elizabeth Mackinlay and Svanibor Pettan, eds. Newcastle upon Tyne: Cambridge Scholars Publishing, 22-35.

Jansen, Stef. 2005. Antinacionalizam. Etnografija otpora u Beogradu i Zagrebu. Beograd: Biblioteka XX vek.

Karača, Tamara. 2001. “Sevdalinka - šta je to?” In Zbornik radova: II. Međunarodni simpozij "Muzika u društvu”. Ivan Čavlović, ed. Sarajevo: Muzikološko društvo FBiH, Muzička akademija u Sarajevu, 247-250.

Karača Beljak, Tamara. 2005. "Bosnian Urban Traditional Song in Transformation. From Ludvik Kuba to Electronic Medias". Traditiones 34/1: 165-176. [http://dx.doi.org/10.3986/ Traditio2005340113]

Karača Beljak, Tamara and Jasmina Talam. 2009. “Ottoman Influence on Folk Music Tradition of Bosnia and Herzegovina”. Muzikološki zbornik 45/1: 117-127.

Kozorog, Miha. "Prilog etnomuzikološkim istraživanjima ratnih izbjeglica iz Bosne i Hercegovine. Nešto između / Sprung”. Muzika: časopis za muzičku kulturu. [In print].

Lomax, Alan. 1959. "Folk Song Style". American Anthropologist 61/6: 927-954. [http://dx.doi. org/10.1525/aa.1959.61.6.02a00030]

Mežnarić, Silva. 1986. “Bosanci”. A kuda idu Slovenci nedeljom? Ljubljana: Krt.

Orth, Jaap. 2005. "Music Therapy with Traumatized Refugees in a Clinical Setting". Voices. A World Forum For Music Therapy 5/2. Available at: https://normt.uib.no/index.php/voices/article/view/227/171 (accessed 13 December 2014).

Pennanen, Risto Pekka. 2007. "Immortalised on Wax. Professional Folk Musicians and Their Gramophone Recordings Made in Sarajevo, 1907 and 1908”. In Europe and Its Other. Notes on the Balkans. Božidar Jezernik, Rajko Muršič and Alenka Batulović, eds. Ljubljana: Faculty of Arts, University of Ljubljana, 107-148.

Pennanen, Risto Pekka. 2010. "Melancholic Airs of the Orient. Bosnian Sevdalinka Music as an Orientalist and National Symbol". In Music and Emotions. Studies across Disciplines in the Humanities and Social Sciences, 9. Risto Pekka Pennanen, ed. Helsinki: Helsinki Collegium for Advanced Studies, 76-90.

Pesek, Albinca. 1996. "Music as a Tool to Help Refugee Children and Their Mothers. The Slovenian Case". In War, Exile, Everyday Life. Cultural Perspectives. Renata Jambrešić Kirin and Maja Povrzanović, eds. Zagreb: Institute of Ethnology and Folklore Research, 257-263.

Petrović, Davor. 2013. “Čovek peva posle rata. Dva koncerta sevdalinke u beogradskom Sava centru kao jugonostalgični rituali pomirenja”. Antropologija 13/1: 111-119.

Pettan, Svanibor. 1995. "Uloga znanstvenika u stvaranju pretpostavki za suživot. Ususret primijenjenoj etnomuzikologiji”. Narodna umjetnost 32/2: 217-234. 
Pettan, Svanibor. 1996. "Making the Refugee Experience Different. 'Azra' and the Bosnians in Norway". In War, Exile, Everyday Life. Cultural Perspectives. Renata Jambrešić Kirin and Maja Povrzanović, eds. Zagreb: Institute of Ethnology and Folklore Research, 245-255.

Pettan, Svanibor. 2009. "Sevdalinka u Norveškoj. Ususret aplikativnoj etnomuzikologiji”. Muzika 13/1: 68-78.

Rasmussen, Ljerka V. 2002. Newly Composed Folk Music of Yugoslavia. New York, Abingdon: Routledge.

Reyes Schramm, Adelaida. 1986. "Tradition in the Guise of Innovation. Music among a Refugee Population". Yearbook for Traditional Music 18: 91-101. [http://dx.doi.org/ 10.2307/768522]

Reyes Schramm, Adelaida. 1989. "Music and Tradition. From Native to Adopted Land through the Refugee Experience". Yearbook for Traditional Music 21: 25-35. [http://dx.doi. org/10.2307/767766]

Reyes, Adelaida. 1999. "From Urban Area to Refugee Camp. How One Thing Leads to Another". Ethnomusicology 43/2: 201-220. [http://dx.doi.org/10.2307/852733]

Stankovič, Peter. 1999. "Rokerji s konca tisočletja”. In Urbana plemena - subkulture na Slovenskem $v$ devetdesetih. Peter Stankovič, Gregor Tomc and Mitja Velikonja, eds. Ljubljana: Študentska založba, 43-52.

Tahirbegović, Farah. 1994. Pismo roditeljima. Ljubljana: Vodnikova domačija.

Terseglav, Marko. 2001. "Ljudska glasba kot identiteta in kot eksotika”. In Zbornik radova: II. Međunarodni simpozij "Muzika u društvu". Ivan Čavlović, ed. Sarajevo: Muzikološko društvo FBiH, Muzička akademija u Sarajevu, 258-266.

Vrečer, Natalija. 2007. Integracija kot človekova pravica. Prisilni priseljenci iz Bosne in Hercegovine v Sloveniji. Ljubljana: Založba ZRC, ZRC SAZU.

\section{SEVDALINKA U IZGNANSTVU PO DRUGI PUT: GLAZBOVANJE MLADIH BOSANSKIH IZBJEGLICA U LJUBLJANI TIJEKOM 1990-IH (BILJEŠKA O APLIKATIVNOJ ETNOMUZIKOLOGIJI)}

Znanstvenici su pojavu sevdalinke u izgnanstvu interpretirali kao manifestaciju izbjegličkog bosanskog identiteta. Iako je ovaj aspekt značajan, vjerujemo da je identitetna dimenzija sevdalinke preuveličana. Zato ukazujemo na pojavu sevdalinke u Sloveniji kao, s jedne strane, dio kompleksnoga procesa suočavanja s neizvjesnošću i traumom, koja je posljedica prisilnih migracija, i s druge, kao odraz mladalačke kreativnosti ili traganja za ekspresivnom slobodom. Naime, tako fokus istraživanja izbjegličkog glazbovanja preusmjeravamo s kolektivnog iskustva na izrazito individualizirane, osobne naracije. Članak ukazuje na to da su glazbene aktivnosti izbjeglica bile u mnogim aspektima organizirane. U njihovoj su organizaciji sudjelovali i etnomuzikolozi, stoga djelovanje aplikativne etnomuzikologije, koja uključuje i praksu strateške esencializacije glazbe, valja analizirati kao integralni dio izbjegličkog glazbovanja.

Ključne riječi: sevdalinka, rat u Bosni i Hercegovini, aplikativna etnomuzikologija, glazba izbjeglica, mladi u izbjeglištvu 